\title{
Teaching NeuroImages: Pseudo-optic disc edema from vitreopapillary traction
}

Stephanie N. Kletke, MD, and Jonathan A. Micieli, MD, CM

Neurology ${ }^{\circledR}$ 2019;93:e317. doi:10.1212/WNL.0000000000007785

Correspondence

Dr. Micieli

jmicieli@

kensingtonhealth.org

Figure Vitreopapillary traction demonstrated with optical coherence tomography

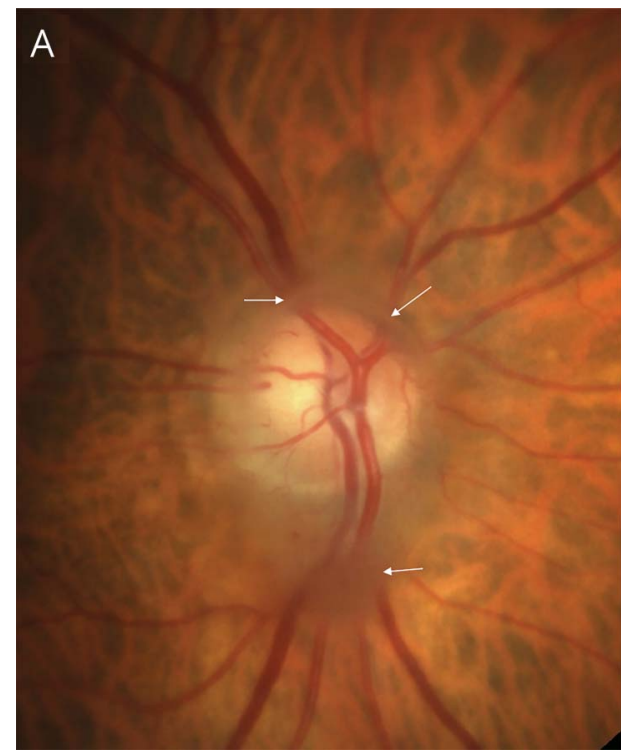

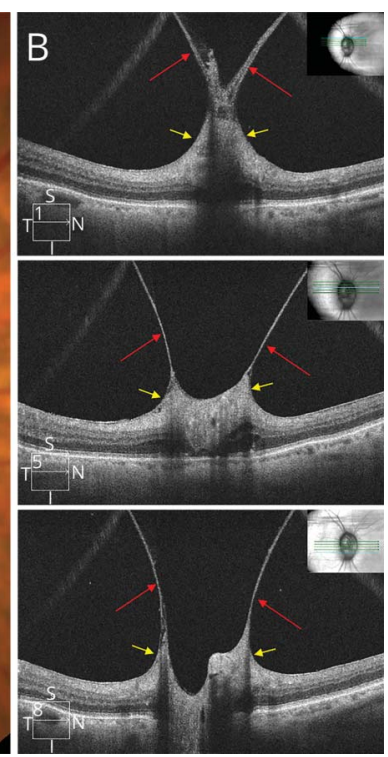

(A) Color photograph of the right optic nerve with areas of obscuration of the retinal vessels (white arrows). (B) Optical coherence tomography sections through the optic nerve superiorly (top) to inferiorly (bottom) confirm the diagnosis of vitreopapillary traction. The hyaloid face of the vitreous is indicated by the red arrows and the optic nerve substance is indicated by the yellow arrows.
A 44-year-old asymptomatic man was noted to have a change in the appearance of his right optic nerve on a routine follow-up. Visual function was normal and there was no relative afferent pupillary defect. Optic disc margins were blurred and there was obscuration of the peripapillary retinal vessels in the right eye (figure, A). Optical coherence tomography (OCT) confirmed the diagnosis of vitreopapillary traction (figure, B) creating a pseudo-optic disc edema appearance. Vitreopapillary traction is included in the differential diagnosis of asymptomatic unilateral optic disc edema and OCT sections through the optic nerve head should be considered in these cases.

\section{Author contributions}

J. Micieli: study conception and design, data acquisition, manuscript preparation, final approval. S. Kletke: study conception and design, data acquisition, manuscript preparation.

\section{Study funding}

No targeted funding reported.

\section{Disclosure}

The authors report no disclosures relevant to the manuscript. Go to Neurology.org/ $\mathrm{N}$ for full disclosures.

\section{MORE ONLINE}

$\rightarrow$ Teaching slides

links.lww.com/WNL/

A921

From the Department of Ophthalmology and Vision Sciences (S.N.K., J.A.M.), University of Toronto; and Kensington Vision and Research Centre (J.A.M.), Toronto, Canada. Go to Neurology.org/N for full disclosures. 


\section{Neurology}

\section{Teaching NeuroImages: Pseudo-optic disc edema from vitreopapillary traction}

Stephanie N. Kletke and Jonathan A. Micieli

Neurology 2019;93; 317

DOI 10.1212/WNL.0000000000007785

\section{This information is current as of July 15, 2019}

Updated Information \&
Services

Subspecialty Collections

Permissions \& Licensing

Reprints including high resolution figures, can be found at: http://n.neurology.org/content/93/3/e317.full

This article, along with others on similar topics, appears in the following collection(s):

Optic nerve

http://n.neurology.org/cgi/collection/optic_nerve

Information about reproducing this article in parts (figures,tables) or in its entirety can be found online at:

http://www.neurology.org/about/about_the_journal\#permissions

Information about ordering reprints can be found online:

http://n.neurology.org/subscribers/advertise

Neurology ${ }^{\circledR}$ is the official journal of the American Academy of Neurology. Published continuously since 1951, it is now a weekly with 48 issues per year. Copyright @ 2019 American Academy of Neurology. All rights reserved. Print ISSN: 0028-3878. Online ISSN: 1526-632X.

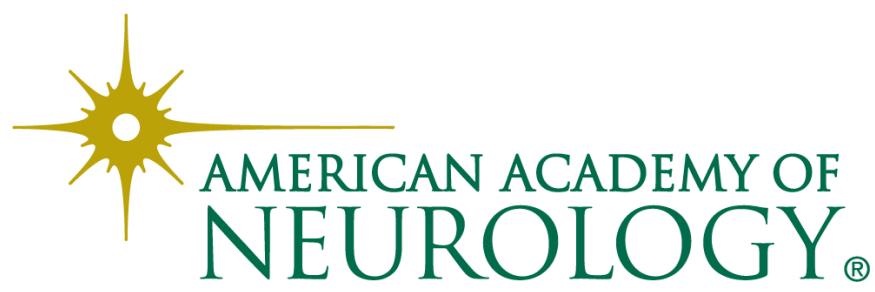

